\title{
STRATEGI MASYARAKAT NELAYAN KEDONGANAN MENGHADAPI KEMISKINAN
}

\author{
Purwadi Soeriadiredja \\ FIB UNUD \\ kuyahambu@yahoo.com
}

\begin{abstract}
Abstrak
Kemiskinan dan keterbelakangan masyarakat nelayan, serta kerusakan lingkungan pesisir dan laut merupakan dampak dari kebijakan pembangunan yang selama ini berorientasi ke daratan. Sekalipun pemerintah menggulirkan kebijakan modernisasi perikanan untuk meningkatkan kesejahteraan nelayan, namun hasil yang dicapai belum memuaskan. Secara umum nelayan masih terperosok dalam perangkap kerentanan sosial-ekonomi berkepanjangan. Kenyataan tersebut membuat perekonomian nelayan memprihatinkan. Kedonganan terletak di kawasan wisata dan menjadi tujuan wisata pantai dan kuliner, namun hal itu bukan jaminan bagi para nelayan dapat meningkatkan kualitas hidupnya. Awalnya perkembangan di Kedonganan tanpa kendali sehingga menimbulkan banyak permasalahan di bidang ekonomi, sosial, budaya, dan lingkungan. Hal tersebut ditengarai akan menimbulkan ketidakharmonisan dan mencoreng citra objek wisata Kedonganan, bahkan pariwisata budaya Bali. Dengan berjalannya waktu, kini pantai Kedonganan berubah menjadi tujuan wisata pantai dan kuliner yang menarik. Hal tersebut tak lepas dari peran Desa Adat Kedonganan yang telah melibatkan masyarakat mulai dari perencanaan awal, pengelolaan dan evaluasi dengan tujuan meningkatkan perekonomian masyarakat, mempertahankan adat istiadat setempat dan pengelolaan yang berkelanjutan. Dalam hal ini bagaimana masyarakat Kedonganan dengan kearifanlokalnya menciptakan strategi dalam menghadapi salah satu permasalahan hidup mereka, yaitu kemiskinan, sehingga lambat laun terjadilah peningkatan ekonomi, sosial-budaya yang signifikan.Sebagai nelayan, bermacam resiko dari pekerjaan sudah biasa mereka hadapi dan terima dengan besar hati karena bagi mereka hidup adalah sebagai anugerah. Suatu hal yang mereka harapkan adalah terciptanya keselarasan dan keserasian antara kehidupan duniawi dan kehidupan dengan Sang Hyang Widi. Untuk itu hidup harus dilandasi dengan sikap pasrah dan menerima apa adanya. Namun bukan berarti harus tetap tinggal diam saja. Pengelolaan pantai Kedonganan berbasis masyarakat ini dijiwai oleh filosofi Tri Hita Karana, karenanya hubungan masyarakat dengan lingkungan (alam, spiritual dan antar manusia) dapat terjalin secara harmonis dan berkelanjutan.
\end{abstract}

Kata Kunci : Strategi, Nelayan, Kemiskinan.

\section{PENDAHULUAN}

Mubyarto dkk. (dalam Kinseng, 2014:38-39) mengemukakan bahwa keluarga nelayan umumnya lebih miskin daripada keluarga petani atau pengrajin. Para nelayan kecil dan buruh nelayan berada pada posisi yang lemah dan marginal. Penguasaan dan akses terhadap sumber daya alam sering menjadi isu utama dalam konflik sosial. Kusnadi (2002) mengungkapkan bahwa kemiskinan, keterbelakangan masyarakat nelayan, kerusakan lingkungan pesisir dan laut merupakan dampak dari kebijakan pembangunan yang selama ini berorientasi ke daratan. Sekalipun pemerintah menggulirkan kebijakan modernisasi perikanan untuk meningkatkan kesejahteraan nelayan, namun hasil yang dicapai tidak memuaskan. Secara umum nelayan masih terperosok dalam perangkap kerentanan sosial-ekonomi yang berkepanjangan. Kenyataan tersebut membuat perekonomian nelayan memprihatinkan.
Beberapa dekade terakhir, masyarakat nelayan Kedonganan masih mengalami keadaan yang memprihatinkan itu. Hal tersebut diketahui berdasarkan beberapa hasil penelitian yang mengungkapkan bahwa walaupun para nelayan Kedonganan telah merasakan proses modernisasi bidang perikanan, namun setiap nelayan hanya mampu menangkap ikan maksimal hanya 4,8 $\mathrm{kg}$ /hari saja (Dinas Perikanan dan Kelautan Kabupaten Badung). Menurut Widhianti (2005) meskipun Kedonganan terletak di kawasan wisata, namun hal itu bukan jaminan bagi para nelayan meningkatkan kualitas hidupnya. Berbagai kesulitan hidup ditemui, namun hal itu pun tidak menjadi halangan untuk tetap hidup sebagai nelayan. Penelitian Sucipta mengungkapkan sejak tahun 1995 Kedonganan mulai terjamah perkembangan kepariwisataan dan menjadi tujuan wisata pantai dan kuliner. Sebagai pengaruh dari keberhasilan pendirian kafe-kafe di pantai Jimbaran, masyarakat Kedonganan pun turut 
mendirikan kafe-kafe pula. Namun perkembangan di Kedonganan tanpa kendali sehingga menimbulkan banyak permasalahan di bidang ekonomi, sosial, budaya, dan lingkungan. Hal tersebut dikhawatirkan akan menimbulkan ketidakharmonisan dan mencoreng citra objek wisata Kedonganan, bahkan pariwisata budaya Bali. Ketidakharmonisan bisa diatasi bila masyarakat setempat turut berpartisipasi dalam penguasaan sumber daya alam.

Sejak tahun 2007 Desa Adat Kedonganan didukung oleh Pemkab Badung mulai menata pantai Kedonganan dengan memaksimalkan semua potensi desa termasuk penataan kafe-kafe. Pengelolaan kafe diberikan kepada masing-masing banjar di wilayah Kedonganan. Dengan berjalannya waktu, kini pantai Kedonganan berubah menjadi tujuan wisata pantai dan kuliner yang menarik. Hal tersebut tak lepas dari peran Desa Adat Kedonganan yang telah melibatkan masyarakat mulai dari perencanaan awal dengan tujuan meningkatkan perekonomian masyarakat, mempertahankan adat istiadat setempat dan pengelolaan yang berkelanjutan. Dalam hal ini bagaimana masyarakat Kedonganan menciptakan strategi dalam menghadapi salah satu permasalahan hidup mereka, yaitu kemiskinan.

\section{Pembahasan \\ Kelurahan Kedonganan}

Kelurahan Kedonganan berada di wilayah Kecamatan Kuta, Kabupaten Badung, dan merupakan wilayah (palemahan) Desa Adat Kedonganan. Kelurahan ini terletak di sebelah selatan kota Denpasar dan berjarak -/+ $20 \mathrm{~km}$ dari kota.

Luas wilayah Kelurahan Kedonganan 191 ha, yang sebagian besar dimanfaatkan untuk pemukiman. Sebagian lainnya merupakan hutan, pekuburan dan fasilitas umum. Seacara topografis, Kelurahan Kedonganan merupakan daerah dataran rendah pada ketinggian $31 \mathrm{~m}$ di atas permukaan laut dengan karakteristik wilayah pesisir dan jenis tanah berpasir yang kurang subur untuk pertanian. Di sebelah selatan merupakan tanah berbukit kapur.

Masyarakat Kedonganan merupakan masyarakat yang heterogen. Selain warga "asli" Kedonganan, banyak pula warga masyarakat yang berasal dari wilayah Bali lainnya. Terlepas dari perbedaan wilayah asal, secara keseluruhan penduduk Kedonganan dapat diidentifikasikan sebagai orang Bali. Sedangkan penduduk pendatang dari etnis lainnya adalah Jawa, Madura, dan Cina.

Agama yang dianut secara mayoritas yaitu Hindu. Sedangkan lainnya ialah Islam, Kristen Protestan, Katholik dan Buddha. Orang Kedonganan percaya bahwa segala aktivitas keagamaan yang dilakukan untuk keselarasan dan keteraturan dalam hidup di dunia dan akhirat. Segala aktivitas keagamaan walau dianggap menyita waktu, tenaga dan biaya, namun mereka percaya bahwa hal itulah tanda bakti kepada Ida Sang Hyang Widhi, Tuhan Yang Maha Esa.

Mata pencaharian utama di Kelurahan Kedonganan adalah sebagai nelayan. Selain itu banyak pula bekerja dalam bidang perdagangan sebagai pengusaha kecil dan menengah, industri dan swasta. Hal itu disebabkan oleh semakin berkembangnya sektor pariwisata di Kedonganan.

\section{Potensi Pariwisata}

Wilayah Kedonganan termasuk dalam wilayah Kecamatan Kuta yang merupakan pusat dari pariwisata Bali. Kedonganan merupakan daerah pantai yang potensial sebagai peningkatan hidup masyarakat setempat. Sebelum berkembangnya kepariwisataan, Kedonganan merupakan desa nelayan yang kesehariannya lekat dengan kehidupan dan aktivitas kenelayanan.

Perkembangan kepariwisataan di

Kedonganan tidak bisa dipisahkan dari perkembangan kepariwisataan di daerah Jimbaran. Dalam rencana induk pariwisata Bali tahun 1990, wilayah Kedonganan telah ditetapkan sebagai wilayah wisata (tourist resort). Beroperasinya Hotel Four Seasons Jimbaran Bali pada tahun 1993 membuka peluang bagi masyarakat Jimbaran untuk ikut merasakan dampak positif pariwisata. Dengan banyaknya wisatawan yang datang ke pantai Jimbaran, beberapa penduduk Jimbaran mendirikan warung-warung ikan bakar bagi wisatawan yang ingin menikmati makanan tradisional khas nelayan sambil melihat pemandangan matahari terbenam. Kesuksesan warung-warung ikan bakar di Jimbaran mendorong beberapa warga Kedonganan ikut mendirikan warung ikan bakar pula. Keberadaan warung-warung makan tersebut akhirnya berkembang menjadi kafe sehingga pantai Kedonganan dan Jimbaran dikenal sebagai lokasi untuk aktivitas wisata kuliner. 
Faktor lain yang mendorong berdirinya kafe di sepanjang pantai Kedonganan adalah tidak terserapnya produksi ikan kelompok-kelompok nelayan Kedonganan yang berlimpah pada waktu itu. Pemindahan Tempat Pelelangan Ikan (TPI) ke Jembrana mengakibatkan nelayan Kedonganan harus mengalokasikan biaya dan waktu yang lebih banyak untuk membawa hasil tangkapan ke Jembrana. Selain itu adanya keluhan dari otoritas Bandara Internasional I Gusti Ngurah Rai terhadap pencemaran bau di sekitar perairan pantai Kedonganan dan limbah ikan yang dibuang oleh nelayan Kedonganan di tengah laut. Fakorfaktor tersebut menyebabkan nelayan Kedonganan beranggapan bahwa profesi nelayan tidak lagi menjanjikan sehingga mereka mulai beralih profesi. Salah satu peluang yang menjanjikan pada waktu itu adalah beralih profesi menjadi pengusaha kafe.

Pada awal perkembangan, pendirian kafe di pantai Kedonganan tanpa koordinasi. Warga yang ingin mendirikan kafe datang ke pantai untuk mengkapling area pantai seluas yang diinginkan dan dibutuhkan. Ketika lahan pantai Kedonganan sudah mulai terbatas, warga yang ingin mendirikan kafe tetap memaksakan diri di area yang sempit, yang mengakibatkan garis pantai Kedonganan didominasi oleh bangunan kafe tanpa perencanaan yang baik sehingga lingkungan Pantai Kedonganan menjadi tidak rapih dan terlihat kumuh. Di samping itu banyaknya jumlah kafe yang ada menimbulkan berbagai dampak negatif, antara lain berupa pencemaran sampah dan pencemaran bau yang bersumber dari limbah kafe yang dibuang langsung ke pantai atau ke laut sebagai akibat tidak adanya sistem pengolahan limbah. Hal tersebut tentunya berdampak tidak baik untuk perkembangan kepariwisataan, khususnya di Kedonganan. Untuk menatanya dibutuhkan suatu perencanaan dan pengelolaan yang didukung dan disetujui oleh seluruh warga masyarakat. Suatu penataan yang dilaksanakan dengan konsep berbasis masyarakat.

\section{Kehidupan Nelayan Kedonganan}

Di Kelurahan Kedonganan terdapat empat lembaga tradisional dalam kehidupan bermasyarakat, yaitu desa dinas, desa adat, banjar dan sekaa. Desa dinas bersifat administratif dan kedinasan yang dikepalai oleh Lurah. Para warga komunitas desa dinas disatukan oleh adanya kesatuan fungsi yang dijalankan oleh Kelurahan sebagai kesatuan administratif.
Desa adat adalah kesatuan masyarakat hukum adat di provinsi Tingkat I Bali yang memiliki satu kesatuan tradisional dan tata krama pergaulan hidup masyarakat Hindu secara turun-temurun dalam ikatan Kahyangan Tiga. Desa adat mempunyai wilayah tertentu dan harta kekayaan sendiri serta berhak mengurus rumah tangganya sendiri. Kekuasaan tertinggi di desa adat terdapat pada rapat anggota dan dikepalai oleh seorang bendesa adat. Desa adat Kedonganan memiliki awig-awig, baik tertulis maupun tidak tertulis yang berupa anggaran dasar dan anggaran rumah tangga untuk mengatur stabilitas organisasinya. Awigawig ini sebagai sarana pengikat warga masyarakat desa adat Kedonganan yang dimuat dan disyahkan oleh pejabat berwenang.

Komunitas kecil di Bali disebut banjar. Suatu banjar dikepalai oleh seorang kelian banjar yang bertugas dalam bidang sosial dan kehidupan keagamaan suatu komunitas. Pusat kegiatan warga banjar adalah di bale banjar di mana para warga banjar bertemu dan melakukan kegiatan pada harihari tertentu. Fungsi banjar yang ada di desa adat Kedonganan adalah untuk mewujudkan hidup bergotong royong di kalangan krama banjar, baik dalam keadaan suka maupun duka.

Sekaa adalah lembaga atau kelompok sosial yang lebih kecil dari banjar. Sekaa di Kelurahan Kedonganan merupakan kesatuan dari beberapa orang anggota banjar yang terhimpun atas dasar kepentingan yang sama dalam suatu hal, misalnya sekaa teruna teruni, sekaa gong, sekaa kidung, $d s b$. Pada prinsipnya sekaa yang ada dilandasi oleh prinsip gotong royong, musyawarah dan tujuan khusus. Kegiatan sekaa di samping untuk kepentingan anggotanya, juga banyak membantu kegiatan banjar, bahkan untuk beberapa hal dimanfaatkan oleh banjar.

\section{Hidup Keseharian Nelayan}

Nelayan dapat diartikan sebagai orang yang secara aktif melakukan pekerjaan dalam operasi penangkapan ikan/binatang/tanaman air lainnya. Orang yang hanya melakukan pekerjaan seperti membuat jaring, mengangkut alat-alat perlengkapan ke dalam perahu/kapal, tidak dimasukkan sebagai nelayan. Sedangkan masyarakat nelayan adalah kelompok atau sekelompok orang yang bekerja sebagai nelayan, nelayan kecil, pembudi daya ikan kecil yang bertempat tinggal di sekitar kawasan nelayan (Peraturan Menteri Perumahan Rakyat No. 15/Permen/M/2006). 
Nelayan dapat dibagi menjadi tiga kategori, yaitu nelayan pemilik tradisional, nelayan pemilik semi-modern, dan nelayan buruh. Tiga kategori nelayan ini memiliki ciri-ciri kehidupan sehari-hari yang berbeda antara satu dengan lainnya. Nelayan pemilik tradisional biasanya memiliki beberapa jukung lengkap dengan segala perlengkapannya (jaring dan mesin tempel), dan mempunyai beberapa orang nelayan buruh untuk mengoperasikan jukungnya tadi. Nelayan pemilik tradisional, wajib membagi uang hasil tangkapan kepada buruh-buruhnya.

Nelayan pemilik semi-modern dibesarkan dalam keluarga nelayan dan memiliki beberapa atau banyak jukung yang pengoperasiannya dipercayakan kepada nelayan buruh. Dia tidak ikut melaut, hanya membantu menyiapkan perlengkapan yang akan dibawa melaut, mengawasi penurunan ikan hasil tangkapan. Hasil tangkapan didistribusikan ke sejumlah hotel, restoran dan kafe yang ada di Kedonganan, dan ada yang dijual di pasar.

Adapun nelayan buruh bekerja pada salah seorang pemilik jukung. Bertugas menyiapkan peralatan dan perlengkapan yang akan dibawa melaut, antara lain; lampu, jaring, bahan bakar mesin tempel. Setelah itu pergi melaut dan kembali membawa ikan hasil tangkapan.

Hingga saat ini, usaha penangkapan ikan yang dilakukan oleh para nelayan Kedonganan dapat dikatakan masih menggunakan teknologi tradisional, seperti jukung, jaring, dayung, dan motor tempel. Alat penangkapan ikan tersebut dikatakan tradisional apabila dibandingkan dengan peralatan yang lebih modern, seperti alat pukat harimau dan perahu besar yang memiliki wilayah tangkapan yang lebih jauh (off-shore fishing) dan kapasitas untuk memperoleh ikan yang lebih banyak.

Beberapa tahun yang lalu peralatan modern telah dikenalkan pula oleh Dinas Perikanan dan Kelautan Republik Indonesia, selain untuk memperkenalkan alat penangkapan ikan modern, peralatan ini dianggap dapat meningkatkan taraf hidup masyarakat nelayan dengan hasil tangkapan yang lebih banyak. Penggunaan peralatan modern tersebut diharapkan dapat mengubah pola penangkapan ikan yang sebelumnya tergantung pada musim menjadi tidak tergantung lagi pada musim. Namun hal tersebut ternyata tidak berlangsung lama, karena selain adanya kesenjangan yang sangat besar antara nelayan dengan peralatan modern dengan nelayan tradisional, hal lainnya adalah kelurahan Kedonganan merupakan salah satu daerah kawasan pariwisata di kabupaten Badung Selatan yang dikembangkan sebagai kawasan wisata pantai. Aktivitas nelayan Kedonganan berupa pendaratan basil tangkapan dialihkan ke Kabupaten Jembrana, karena hal itu dianggap dapat mempengaruhi kebersihan dan keindahan wisata alam di Kedonganan. Hal itulah yang menyebabkan nelayan Kedonganan memilih kembali dengan peralatan tradisional mereka.

\section{Pengelolaan dan Pemasaran Hasil Tangkapan Ikan}

Pada musim panen ikan, yaitu pada bulan Maret-Agustus para nelayan Kedonganan hanya mencari ikan di sekitar pantai saja. Sedangkan pada bulan September-Desember mereka mencari ikan sampai ke tengah laut. Hal itu disebabkan pada bulan-bulan tersebut merupakan musim hujan di mana ikan laut relatif sulit diperoleh. Ada beberapa ikan yang yang selalu ada pada musim ikan seperti tongkol dan lemuru. Pada musim ikan, suasana di pantai biasanya tampak ramai dengan aktivitas kenelayanan.

Secara umum, pengolahan hasil tangkapan ikan yang dilakukan nelayan di Kabupaten Badung adalah pemindangan, pembekuan dan pengasinan. Namun demikian, nelayan Kedonganan lebih banyak menjual hasil tangkapannya ketika ikan masih segar dan dengan cara pembekuan agar ikan bisa dijual keesokan harinya. Untuk mengatasi proses pembusukan sehingga mengalami kemunduran mutu, para nelayan Kedonganan melakukan pengawetan dengan es.

Setiap nelayan pemilik, pada musim ikan mampu menghasilkan hasil tangkapan sebanyak 3-5 ton dengan jumlah kepemilikan 3-6 jukung. Hanya pada tidak musim ikan produksi ikan menurun menjadi kurang dan 1 ton. Hasil tangkapan berupa ikan segar langsung ditimbang di TPI (Tempat Pelelangan Ikan). Tersediannya prasarana tempat pelelangan ini, diharapkan para nelayan dapat memanfaatkannya sebagai tempat penjualan pertama setelah ikan ditangkap di laut. Hasil tangkapan nelayan dijual dengan sistem lelang. Hal itu dimaksudkan agar ikan hasil tangkapan nelayan tidak dipermainkan oleh pengambek (tengkulak). Ukuran yang digunakan untuk menimbang adalah ember ukuran besar. Biasanya sebelum para nelayan kembali dari menangkap ikan, para ijon telah menunggu di 
pantai. Para pembeli ini umumnya para pedagang yang menjual lagi hasil tangkapan nelayan ke pasar-pasar di seluruh Bali. Aspek yang menentukan dalam kaitannya dengan kegiatan kenelayanan dan yang berpengaruh langsung terhadap peningkatan kesejahteraan hidup nelayan adalah aspek produksi dan distribusi hasil tangkapan. Apabila hubungan sosial yang melingkupi kedua aspek tersebut kurang menguntungkan nelayan dan nelayan buruh, maka kelembagaan KUD perlu diberdayakan sesuai dengan kebutuhan masyarakat untuk mengatasi hubungan-hubungan sosial ekonomi yang timpang. Di Kedonganan, KUD setempat tidak berfungsi untuk memenuhi kebutuhan modal nelayan. TPI juga tidak berfungsi sebagaimana mestinya, sehingga keberadannya tidak memberikan keuntungan ekonomi kepada nelayan. Bahkan dengan penarikan restribusi, nelayan justru merasa dirugikan. Dalam memenuhi kebutuhan modal usaha, sebagian besar nelayan memilih meminjam uang dari pengambek. Pemasaran hasil tangkapanpun dilakukan tidak melewati sistem KUD yang ada disana, melainkan langsung antara nelayan ke pengambek. KUD hanya menjual hasil tangkapan ikan para nelayan modern dengan kapal besar saja. Oleh karena itu, pendapatan para nelayan sangat sulit dicatat secara pasti. Penghasilan nelayan dapat dikatakan tidak menentu. Hal itu terjadi disebabkan pula oleh para nelayan yang melakukan aktivitas melaut masih berdasarkan musim.

Hasil tangkapan ikan yang rusak dapat dimanfaatkan menjadi tepung untuk makanan ternak unggas, terutama ayam. Selain itu ikan segar yang belum begitu rusak juga dibeli oleh ijon atau pengepul yang kemudian dijual ke pabrik pembuatan ikan sarden. Jika jumlah hasil tangkapan banyak, maka para nelayan menjual kepada ijon ini. Tetapi jika hasil sedikit maka nelayan hanya menjual di pasar. Ikan yang ada di pasar ikan Kedonganan tidak semua dari nelayan Kedonganan, namun dari nelayan daerah lain, seperti Sanur, Benoa, daerah Bali lainnya, bahkan dari Jawa. Selain itu cafe-cafe di Kedonganan tidak selalu membeli ikan di pasar atau dari nelayan Kedonganan, melainkan membeli dari tempat lain dan dari kapal besar yang menjual ikannya lewat TPI.

\section{Perkembangan Kelompok Nelayan}

Pada tahun 1970-an nelayan Kedonganan masih merupakan nelayan tradisional, dalam arti nelayan pada saat itu masih menggunakan peralatan yang masih sederhana seperti jukung, pencar, dayung (kelimat), pancing, serok dan lain sebagainya. Pendapatan dari hasil tangkapan nelayan hanya mencapai $2,5 \mathrm{~kg}$ ikan perhari dengan harga Rp. $1.000,00 / \mathrm{kg}$. Hal tersebut tidak dapat memenuhi kebutuhan sehari-hari dengan layak.

Fenomena tersebut membuahkan suatu inisiatif para nelayan setempat. Pada tahun itu pula berdiri pertama kali kelompok nelayan yang beranggotakan 30 orang. Organisasi ini dibentuk dengan tujuan memantau seluruh aktivitas nelayan dengan segala kekurangan dan keterbatasannya, yang antara lain bertujuan untuk melindungi nelayan dari sistem ijon yang memberi pinjaman modal kepada para nelayan namun sistem tersebut sangat merugikan nelayan. Setahun lamanya kelompok nelayan itu mampu bertahan dengan segala bentuk rintangan dari para ijon yang sempat pula memecah belah kelompok itu dengan menggunakan kekuatan modal yang dimilikinya. Berkat kegigihan pengurusnya melalui berbagai pendekatan kepada para anggota yang telah dikuasai ijon, maka anggota kelompok berkumpul kembali dalam satu wadah organisasi nelayan.

Setelah terbentuk kelompok nelayan yang telah disahkan, Pemerintah Daerah melalui BRI Cabang Denpasar memberikan bantuan kredit berupa KIK (Kredit Investasi Kecil). Untuk tahap pertama direalisasikan pada tahun 1977 yang digunakan untuk membeli 26 unit kapal selerek dan perlengkapannya. Bantuan pemerintah tersebut besar manfaatnya bagi kelompok nelayan, terutama dalam menambah anggota organisasi yang mampu menyerap tenaga kerja sebanyak 260 orang nelayan buruh sekaligus.

Pada tahun 1979 dilaksanakan motorisasi nelayan. Setelah adanya motorisasi, hasil tangkapan nelayan meningkat dengan pesat, pendapatan nelayan terangkat untuk mendukung pembangunan di bidang perikanan. Untuk memperkuat kemajuan yang ingin dicapai, masyarakat nelayan membentuk koperasi Mina Segara yang bertujuan menyediakan modal bagi nelayan anggotanya dengan bunga yang kecil.

Modernisasi perikanan yang terjadi di Kedonganan merupakan suatu proses perubahan yang mempengaruhi kehidupan sosial-ekonomi. Dari segi sosial terlihat makin meningkatnya jumlah kelompok-kelompok kerja dalam aktivitas penangkapan ikan dengan anggota yang tidak 
terbatas dalam lingkungan keluarga saja. Sedangkan dari segi ekonomi terlihat peningkatan taraf hidup nelayan. Sayangnya modernisasi penangkapan ini tidak bertahan lama, ketika kapal dengan alat purse saine dipindahkan pendaratannya ke daerah Kabupaten Jembrana. Para nelayan Kedonganan kembali menggunakan perahu tradisional karena jauhnya tempat pendaratan tadi. Adapun alasan Pemerintah memutuskan untuk memindahkan kapal dengan peralatan purse saine itu karena Kabupaten Badung merupakan daerah yang direncanakan sebagai tujuan pariwisata. Khususnya Kelurahan Kedonganan yang letaknya berdekatan dengan daerah tujuan wisata Kuta, sehingga pendaratan kapal ikan dianggap mempengaruhi pemandangan para wisatawan. Akibatnya hasil mata pencaharian nelayan mengalami penurunan setiap tahunnya. Dari sejumlah 15 kelompok nelayan, kini jumlah kelompok nelayan yang masih aktif hanya dua kelompok nelayan saja, yaitu kelompok nelayan Kerta Bali dan kelompok nelayan Putra Bali.

\section{Strategi Menghadapi Kemiskinan \\ Orientasi Nilai Budaya}

Perikanan dan kelautan secara umum telah menjadi ikon Kedonganan. Bahkan, Kedonganan hingga kini menjadi salah satu sentra usaha perikanan dan kelautan terbesar di Bali. Kehadiran Tempat Pelelangan Ikan (TPI) Kedonganan menunjukkan Kedonganan memegang peranan penting dalam bidang perikanan. Namun kualitas sumber daya manusianya masih tertinggal, setidaknya hingga tahun 1990. Kondisi semacam itu berpengaruh kepada iklim usaha untuk mencapai kesejahteraan masyarakat. Berbagai usaha yang dikembangkan di Kedonganan lebih sering menemui kegagalan dan jauh tertinggal dibandingkan daerah-daerah lainnya di Kecamatan Kuta. Meskipun dekat dengan sentra pariwisata, keberadaan Kedonganan tidak bisa ikut merasakan kue pariwisata. Tetapi mereka tidak menyerah, kehidupan harus berjalan terus seiring zaman. Mereka menyusun suatu strategi untuk menghadapi keterpurukan. Dengan menggunakan kearifan dalam kebudayaannya mereka mengadaptasi, menginterpretasi dan mengubah lingkungan sesuai dengan apa yang mereka harapkan.

Nelayan Kedonganan, khususnya nelayan tradisional dan nelayan buruh, mereka harus siap menghadapi ketidakpastian perolehan penghasilan dari melaut. Kadang kala mereka melakukan penangkapan di kawasan perairan yang letaknya cukup jauh dari tempat tinggal mereka. Berbagai resiko pekerjaan sudah biasa mereka hadapi dan terima dengan besar hati, karena bagi mereka hidup adalah sebagai anugerah. Suatu hal yang mereka harapkan adalah terciptanya keselarasan dan keserasian antara kehidupan duniawi dan kehidupan dengan Sang Hyang Widi. Untuk itu hidup harus dilandasi dengan sikap pasrah dan menerima apa adanya. Namun bukan berarti harus tetap tinggal diam saja.

\section{Faktor-faktor Mempertahankan Kenelayanan}

\section{Alam}

Kedonganan merupakan salah satu kawasan wisata pantai. Adanya pembangunan di bidang pariwisata dan perikanan, turut berpengaruh terhadap pola pikir masyarakat Kedonganan yang ingin pula turut menikmati berkah tersebut. Berkaitan dengan kegiatan kenelayanan di Kedonganan, dengan kesadaran sendiri masyarakat nelayan Kedonganan memiliki sikap bahwa laut patut dijaga, dilestarikan keberadaannya, karena ketergantungan masyarakat nelayan Kedonganan terhadap sumber daya laut sangat besar. Hal inilah yang membuat masyarakat nelayan Kedonganan merasa memiliki dan bertanggung jawab terhadap kelestarian laut di sekelilingnya. Untuk itu diberlakukan awig-awig yang mengatur kehidupan masyarakat nelayan berlandaskan filosofi ajaran Agama Hindu dan lekat dengan budaya Bali. Hal tersebut tidak hanya berlaku bagi nelayan pribumi saja, tetapi juga berlaku bagi nelayan pendatang.

\section{Ekonomi}

Perikanan adalah sistem usaha manusia dalam pemanfaatan sumber daya laut, mengolah dan memasarkannya. Pekerjaan sebagai nelayan adalah pekerjaan pokok. Alasan mereka menggeluti mata pencarian sebagai nelayan adalah kondisi perekonomian yang kurang mampu memenuhi kebutuhan keluarga. Dengan mengikutsertakan seluruh anggota keluarga dalam usaha kenelayanan merupakan salah satu alasan dalam memenuhi kebutuhan hidupnya. Namun untuk mencukupi kebutuhan hidup harus diimbangi pula oleh pekerjaan sampingan lainnya, misalkan sebagai pedagang, buruh bangunan, pengrajin, pemandu wisata laut, atau lainnya.

Pariwisata turut andil pula dalam mensejahterakan kehidupan nelayan. Adanya sajian khas kuliner di Kedonganan menyebabkan 
pasokan akan ikan di beberapa hotel, kafe dan restoran juga meningkat. Selain itu bidang pekerjaan lainnya berhasil menciptakan lapangan kerja baru yang memberi peluang untuk menyerap para pencari kerja, khususnya generasi muda Kedonganan. Hal itu dapat mengurangi tingkat pengangguran yang ada di Kedonganan dengan segala aspek negatif ikutannya.

\section{Sosial-budaya.}

Seiring bertambah pesatnya kegiatan kepariwisataan di Kedonganan, sektor penunjang pariwisata seperti hotel, kafe pinggir pantai yang menyajikan hidangan khas laut di Kedonganan semakin kompleks. Hal tersebut tak akan mempengaruhi kehidupan sosial budaya masyarakat setempat. Misalnya dari sebelumnya mereka memiliki gaya dan pola hidup tradisional yang sederhana, kini mulai menjalani gaya dan pola hidup modern seiring dengan kemajuan jaman. Walaupun demikian orang Kedongan tak lupa kepada jati dirinya sebagai warga masyarakat Bali lainnya. Mereka tetap setia menjalankan kewajiban tradisi yang diwariskan dari nenek moyangnya.

Bagi orang Kedonganan, air merupakan elemen pokok dari kehidupan nelayan, elemen pokok yang merupakan suatu bagian dari upacara keagamaan, upacara siklus manusia dari lahir sampai mati. Bagi nelayan Kedonganan menjaga keseimbangan ekologis lautan sangatlah penting. Mereka percaya bahwa bila manusia mengeksploitasi hasil laut secara besar-besaran atau dengan cara-cara yang dilarang oleh adat seperti pengeboman, maka mereka akan mendapat kutukan berupa tidak selamat atau kesulitan dalam memperoleh hasil laut. Pengetahuan tentang kenelayanan seperti itu diturunkan oleh para orang tua yang sejak anak-anak mereka masih kecil dan hidup dari hasil laut. Pengetahuan tentang kenelayanan diperoleh karena mereka selalu mengikutsertakan anak-anak mereka dalam kegiatan melaut. Pengikutsertaan anak-anak ini dalam kegiatan melaut merupakan salah satu pengalihan sistem pengetahuan praktis sehingga ketika dewasa kelak anak-anak tersebut sudah siap menghadapi segala tantangan yang muncul.

Adanya beberapa potensi yang dimiliki ini, masyarakat nelayan Kedonganan menganggap laut merupakan warisan dari nenek moyang yang harus dijaga, dipelihara, dan dimanfaatkan sesuai dengan kebutuhan hidup. Laut merupakan sumber kehidupan yang dianggap sebagai bagian yang tidak bisa lepas dari kehidupan mereka. Apabila laut rusak atau tercemar berarti kehancuran juga bagi kehidupan. Mereka mengeksploitasi hasil laut sesuai dengan yang diajarkan oleh orang-orang tua mereka.

\section{Peran Lembaga Adat}

\section{Perencanaan}

Peran lembaga adat di Kedonganan dalam menyusun strategi menghadapi kemiskinan ini sangat penting, terutama dalam hal mengubah pola pikir masyarakat setempat. Hal itu tak lepas dari keberadaan Desa Adat Kedonganan yang didukung Pemkab Badung untuk menata kawasan pantai Kedonganan sebagai bagian palemahan desa. Panitia penataan kemudian dibentuk untuk mempersiapkan rencana penataan hingga pelaksanaan penataan pantai Kedonganan. Panitia dibentuk melalui sinergi antara tiga lembaga, yaitu Desa Adat Kedonganan, Kelurahan Kedonganan dan Lembaga Pemberdayaan Masyarakat (LPM) Kedonganan. Anggota panitia adalah warga Desa Adat Kedonganan yang memiliki pengetahuan yang dibutuhkan untuk melakukan perencanaan di bidang pariwisata. Kepanitiaan bekerja dengan baik karena dukungan penuh dari para tokoh masyarakat dan para pemudanya sehingga sebagian besar warga Desa Adat Kedonganan memberi dukungan terhadap rencana penataan ulang pantai Kedonganan. Selain itu desa adat dibantu secara finansial oleh LPD (Lembaga Perkreditan Desa) Desa Adat Kedonganan.

\section{Pelaksanaan}

Pada saat didirikan, LPD Desa Adat Kedonganan dalam kondisi serba terbatas. Tidak hanya terbatas modal tetapi juga dukungan krama karena ragu lembaga ini bisa eksis dan berlanjut. Lambat laun, seiring bertumbuhnya kegiatan usaha LPD, kepercayaan krama dan nasabah juga ikut tumbuh. LPD Kedonganan pun berkembang pesat.

Sejak tahun 2007 Desa Adat Kedonganan yang didukung Pemkab Badung, dan secara internal didukung oleh LPD Desa Adat Kedonganan menata kawasan pantai Kedonganan sebagai bagian palemahan desa. Penataan pantai Kedonganan pada dasarnya merupakan proses pengalokasian area pantai Kedonganan ke dalam zona-zona tertentu, yaitu zona kafe, zona ekonomi, zona sosial-budaya dan keagamaan berdasarkan gambar rencana yang telah disetujui. Penataan juga merupakan usaha untuk mengurangi jumlah kafe 
yang sudah berdiri sebelumnya dari sejumlah 67 menjadi 24 di mana kepemilikannya diserahkan kepada seluruh warga Desa Adat Kedonganan yang tersebar di enam banjar sesuai Rekomendasi Bupati Badung. Masing-masing banjar diberi hak mengelola empat kafe. Ini merupakan salah satu strategi untuk meningkatkan kesejahteraan masyarakat Desa Adat Kedonganan melalui usaha bersama dengan memanfaatkan palemahan desa di pesisir barat.

Sejak saat itu pantai Kedonganan dikenal sebagai daerah wisata kuliner yang sangat menarik. Pemandangan lautnya tak kalah menawan dengan objek wisata pantai lainnya. Nama Kedonganan pun mulai disebut-sebut di dunia pariwisata. Sejumlah situs internet menurunkan laporan mengenai suasana pantai Kedonganan sebagai alternatif objek wisata pantai maupun wisata kuliner di Bali.

\section{Pengawasan dan Evaluasi}

Pengawasan yang dilakukan Desa Adat Kedonganan berlandaskan awig-awig yang berlaku di wilayah itu. Awig-awig merupakan sekumpulan aturan baik tertulis maupun tidak tertulis yang dibuat berlandaskan ajaran agama Hindu Tri Hita Karana yang mengajarkan keharmonisan atau keseimbangan hubungan antara manusia dengan manusia, manusia dengan Tuhan dan manusia dengan lingkungan. Ada tujuh aturan lokal atau larangan pada Awig-awig dalam pengaturan kehidupan masyarakat nelayan di Kedonganan, yaitu:

1. Larangan mengambil ikan menggunakan pukat harimau, bom, potasium dan bahan kimia berbahaya lainnya.

2. Larangan merusak terumbu karang secara sengaja.

3. Larangan mengambil biota laut yang dilindungi.

4. Larangan melaut pada Hari Raya Nyepi.

5. Larangan melaut pada saat berlangsungnya upacara keagamaan setempat.

6. Larangan membuang sampah di sekitar pantai dan pesisir.

7. Larangan melaut pada angin musim barat

Tujuan dibentuknya awig-awig tersebut adalah untuk memberi pedoman berperilaku pada nelayan dalam hidup bermasyarakat, khususnya dalam kegiatan penangkapan ikan dan menjaga keutuhan masyarakat nelayan. Selain itu awig-awig mempunyai tujuan agar keseimbangan hubungan dan keharmonisan yang terkandung dalam ajaran Tri Hita Karana tetap dipertahankan seiring dengan perkembangan jaman. Sebagai wujud dari pengawasan sosial, maka diberlakukan pula sanksi untuk setiap bentuk pelanggaran. Sanksi yang diterapkan merupakan satu wujud upaya represif. Semua aturan atau larangan dalam awig-awig disosialisasikan sebagai bentuk proses penanaman nilai-nilai dan aturan adat dalam lingkungan masyarakat. Agar pelaksanaan pengawasan lebih optimal, pada tahun 2007 dibentuk Badan Penataan Kawasan Pariwisata Pantai Kedonganan (BPKP2K) yang bertugas sebagai pelaksana kebijakan tiga lembaga pembentuk terkait penataan pantai Kedonganan, dan sebagai pengawas Kawasan Pantai Kedonganan. Badan tersebut kini menjadi Badan Pengelola Kawasan Pariwisata Pesisir Kedonganan (BPKP2K) dan diharapkan mampu memastikan agar pariwisata berbasis masyarakat mampu berjalan dalam kaidah-kaidah keberlanjutan serta dapat memberikan berbagai dampak positif bagi Desa Adat Kedonganan. Setelah itu dibentuk pula Panitia Pelaksana Pembuatan Perarem (Peraturan Desa Adat) dengan tujuan untuk memastikan keberlanjutan kepariwisataan di pantai Kedonganan, melalui seperangkat peraturan dalam pengelolaan kafe dan penataan kawasan pantai Kedonganan. Pariwisata berkelanjutan itu pada dasarnya merupakan pariwisata yang memanfaatkan sumber daya alam dengan bijaksana dan tetap mengupayakan pelestariannya.

Setelah BPKP2K terbentuk, warga masyarakat tetap mengawasi pengelolaan dan pengembangan kepariwisataan melalui mekanisme perwakilan. Setiap Kepala Lingkungan dan Kepala Adat (Kelihan Banjar) duduk sebagai anggota dewan pengawas BPKP2K. Dewan pengawas tersebut setiap bulan memperoleh laporan dari BPKP2K melalui mekanisme rapat bulanan. Laporan tersebut diteruskan kembali ke seluruh krama (warga) banjar pada saat sangkep atau paruman (rapat) sehingga seluruh warga mengetahui perkembangan kepariwisataan pantai Kedonganan termasuk perkembangan kafe yang mereka miliki.

4. Hubungan Pihak Pengelola dengan Masyarakat Pembangunan kepariwisataan atau pengelolaan sumber daya laut harus mampu berkontribusi dalam menjaga keberlanjutan lingkungan alam, sosial-budaya dan ekonomi dimana ketiganya merupakan pilar-pilar keberlanjutan. Pengelolaan berbasis masyarakat 
diimplementasikan dengan pendekatan bottom-up, di mana hal ini sebenarnya mengedepankan peranserta masyarakat sebagai prinsip utamanya. Peranserta tersebut terwujud dari tersedianya kesempatan bagi masyarakat untuk terlibat penuh mulai dari proses perencanaan, pelaksanaan, pengawasan dan evaluasi, selanjutnya sebagai penikmat dari manfaat yang ditimbulkan.

Perkembangan bisnis kafe di pantai Kedonganan sangat menjanjikan. Hal tersebut dimungkinkan karena ramainya pantai Kedonganan dikunjungi oleh para wisatawan, baik wisatawan lokal maupun manca negara. Tingginya tingkat pengembalian investasi kafe di pantai Kedonganan mampu meningkatan kondisi keuangan Desa Adat Kedonganan sehingga mampu memberikan banyak manfaat bagi warganya. Manfaat tersebut terutama berkaitan dengan meningkatnya kemampuan Desa Adat Kedonganan sebagai lembaga adat untuk melaksanakan berbagai aktivitas tanpa harus memungut biaya dari warga masyarakat. Mereka mampu menyediakan dan memberikan berbagai fasilitas bagi kesejahteraan warga Desa Adat Kedonganan.

Untuk meningkatkan kualitas sumber daya manusia (SDM), lembaga adat melalui LPD berperan aktif mengadakan program dalam bidang pendidikan, kesehatan serta sosial-budaya. LPD memberikan beasiswa berprestasi dan beasiswa bagi anak yang kurang mampu. Selain itu LPD juga menyelenggaran tabungan untuk pendidikan, mendirikan lembaga pendidikan desa adat Kedonganan yang diharapkan mampu memberikan sumbangan pemikiran dan melaksanakan kegiatan yang dapat mendorong peningkatan kualitas pendidikan di kelurahan Kedonganan. Demikian pula banyak kegiatan sosial-budaya lainnya yang dilaksanakan untuk kepentingan warga masyarakat tanpa dikenakan biaya sedikitpun.

Kesejahteraan warga masyarakat makin meningkat. Oleh karena itu, tidak heran bila sebelumnya banyak nelayan Kedonganan hanya di tingkat "kelas buruh" saja, kini mereka sudah menjadi "kelas majikan". Tidak jarang dari para nelayan "kelas majikan" ini mempunyai lebih dari tiga perahu dengan beberapa nelayan buruh yang menjadi bawahannya.

\section{SIMPULAN DAN SARAN}

Simpulan

Pada awalnya, masyarakat nelayan desa adat Kedonganan dapat dikategorikan sebagai masyarakat miskin, dalam arti belum bisa mengelola sumber daya laut yang mereka miliki untuk meningkatkan kesejahteraan hidup mereka. Hasil perkembangan kepariwisataan pun belum dirasakan oleh masyarakat, karena pengelolaannya belum tertata rapi. Namun sejak tahun 2007 desa adat Kedonganan melalui para pemuka desanya menciptakan strategi baru dalam menghadapi kemiskinan tersebut. Mereka merencanakan, melaksanakan, dan melakukan pengawasan terhadap pengelolaan sumber daya alam di wilayahnya. Diawali dengan pengelolaan pantai dengan kafe-kafe yang ada di pantai Kedonganan. Pengelolaan kafe-kafe tersebut diserahkan kepada masyarakat melalui banjar. Masyarakat dilibatkan sejak awal pendirian, pengelolaan dan evaluasi yang benar-benar dirasakan oleh masyarakat Kedonganan. Terjadilah peningkatan ekonomi, sosial-budaya yang signifikan. Pengelolaan pantai Kedonganan berbasis masyarakat ini dijiwai oleh filosofi Tri Hita Karana, karenanya hubungan masyarakat dengan lingkungan (alam, spiritual dan antar manusia) dapat terjalin secara harmonis dan berkelanjutan.

Saran

Masyarakat Kedonganan diharapkan tetap menjaga keseimbangan hubungan dengan lingkungan, baik alam, spiritual maupun antar manusia. Secara lahiriah, yang harus lebih diperhatikan adalah kebersihan lingkungan, dan tersedianya lahan parkir yang cukup luas. Karena bagaimana pun kini Kedonganan menjadi tujuan wisata pantai dan kuliner yang cukup populer.

Untuk meningkatkan keefektivitasan awigawig atau perarem, maka perlu dilakukan evaluasi terhadap beberapa peraturan yang ada sehingga dapat dilakukan perbaikan. Aturan-aturan dan sanksi-sanksi yang diterapkan harus tegas, dan jumlah petugas pemantau ditingkatkan, baik secara kualitas maupun kuantitas. ***

\section{Daftar Pustaka}

Kusnadi. 2002. Konflik Sosial Nelayan, Kemiskinan dan Perebutan Daya Perikanan. Yogyakarta: LKiS. 
Rilus, A. Kinseng. 2014. Konflik Nelayan. Jakarta: Yayasan Pustaka Obor Indonesia.

Sucipta, Abdi Md. 2012. Pengelolaan Pantai Kedonganan Sebagai Daya Tarik Wisata Kuliner Berbasis Masyarakat di Desa Kedonganan, Media Bina Ilmiah, Volume 6, no. 6, Desember 2012, 24-28.

Widhianti, N.M.D. Safitri. 2005. Orientasi Nilai Budaya Masyarakat Nelayan di Kawasan Wisata Kedonganan, Kelurahan
Kedonganan, Kabupaten Badung, Bali. Denpasar: Prodi Antropologi FSB UNUD.

Peraturan Menteri Perumahan Rakyat No. 15/Permen/M/2006.

kelurahankedonganan.blogspot.co.id, Profil Kelurahan Kedonganan

www.lpdkedonganan.com, LPD Desa Adat 